\title{
Reactualization of Indonesia- India Bilateral Relations ${ }^{1}$
}

\section{Gonda Yumitro}

Departement of International Relations, University of Muhammadiyah Malang

Kampus Telogo Mas, Malang 65144

Email: yumitro@gmail.com

\begin{abstract}
After liberalized it's economic policy in 1991, India emerges as a new emerging power in the world. By the year, it's economic power supports the strengthening of it's politics, military and cultures. Such condition invited Indonesia to be closer to India as what they had in previous time, since both countries also have consciousness on the emergence of Asian century after American and Europe have become weaker. Through this paper, I will position Indonesia and India mapping in International politics, particularly in term of their economic power. By this effort, it will be clear how important the reactualization of Indonesia-Indian bilateral relations in this globalized era. I also will analyze the prospect and obstacles of both countries relations.
\end{abstract}

Keyword: Indonesia, India, Bilateral, Economic, International, Regional

\begin{abstract}
Abstrak
Setelah meliberalkan kebijakan ekonomi pada 1991, India muncul sebagai kekuatan baru di dunia. Dari tahun ke tahun, kekuatan ekonomi mempengaruhi penguatan politik, militer, dan budaya. Kondisi tersebut mengundang Indonesia untuk lebih dekat ke India seperti sebelumnya, karena kedua negara juga sadar akan kemunculan abad Asia, setelah Amerika dan Eropa mulai melemah. Melalui artikel ini, saya akan memposisikan pemetaan Indonesia dan India dalam politik internasional, khususnya dalam hal kekuatan ekonomi. Dalam upaya ini, maka akan jelas betapa pentingnya reaktualisasi hubungan bilateral Indonesia-India di era globalisasi. Saya juga akan menganalisa prospek dan hambatan hubungan kedua negara.

Kata Kunci : Indonesia, India, bilateral, ekonomi, internasional, regional
\end{abstract}

\section{INTRODUCTION}

Indonesia India bilateral relations steadily become more significant. On 26 January, 2011, India invited Susilo Bambang Yudhoyono (SBY), Indonesian president, as the Chief Guest of republic day in India. In the same momentum, both countries, Indonesia and India leaders also signed 17 Memorandum of Understanding $(\mathrm{MoU})$ as the the evidence of commitment both countries to build better relations in the future (www.idsa.in).

In this meeting, India must had already thought the important of Indonesia in her foreign policy so she invited Indonesian president as the Chief Guest (Endi Bayuni: 2011). At least India wants to rebuild the good relations of both countries which was so close in the era of Soekarno, after both of them freed them selves from the shakles of colonialism. Moreover, India gave the signal to Indonesia that both of them need to enclose their relations.

This momentum was also interesting because India had invited Indonesian first president, Soekarno, as the Chief Guest at January 26, 1950. Indonesia and India were so close because they were the founders and main actors of non-alignment movement which became hot issue in that time. Moreover India supported Indonesia in United Nation to be free from reintervention of Dutch. When president SBY was invited as the second Chief Guest from Indonesia in 2011, some people saw that it was the momentum of both countries to re-emerge the closer relations. 
Moreover, in December 2012, president SBY for the third times visited India in official manner to discuss various Issues. On the other side, on October 10-20, 2013, Indian Prime Minister, Manmohan Singh came to Indonesia in order to expand the cooperation becomes closer and produce mutual benefits for both countries. This conditions show that the bilateral relations of Indonesia - India has become reactualized.

In this essay, I will discuss the importance of Indonesian foreign policy reactualization toward India. To make such explanation clearly in understanding, I will explain the dynamics relations of both countries since previous time until now. That relation also will be seen in two aspects, politics and economic relations. In the end, I will discuss the potencies and challenges of cooperation between both countries to see the feasibility of the future cooperation.

\section{ANALYSIS}

\section{INDIA AS A NEW EMERGING POWER}

Basically, the popularity of India as a new emerging power has been started since 1998. In that time, the liberalization policy within the economic system of India since 1990 has shown its result where the GDP of India has been increasing steadily. Such reality was different with the condition of India when she implemented the socialistic policy before 1990 .

In spite of various factors, such high standard of education, and the developments of its technology, the existence of India in this era also has been influenced by its big number of population which becomes the strategic resources of workers and markets. This condition cannot be separated by the education policy of Indian government which supports Internationalization of Indian education, though the price is still so cheap, so that the number of experts and scholars who are globally recognized in various fields are increasing every years in India.

In such condition, the economic development of India is running so fast and creates this country as the second fastest market in the world after Chinese. At less around 250 millions of Indian people become the middle class within the country, though the gaps between the rich and poor are still very huge. But as the result, it cannot be neglected that India has emerged as a very strategic market in the world.

Some countries which have interests in the Indian development started to build close relations toward India. For Instance, United State of America (USA) which had very close relation to Pakistan, the enemy of India, has changed its policy and intensity mutual cooperation with India in various aspects, including for the development of Indian nuclear power. India, which was stronger power in many aspects such as in its economic, political and military comparing to its neighbor countries, becomes new "hegemonic" power in the region. Furthermore, India has strengthens its military power for avoiding unexpected condition because of its unfriendly relations with some other neighbor countries namely Pakistan, China and Bangladesh. Even India has started to expand its market through building intensive cooperation with another region outside South Asian.

It such very fast development of Indian position in International politics has become International issues. As a country which has direct border to India and had strong cultural and economic relations since long times ago, Indonesia needs to reactualize its views on India. We need to understand India objectively and realize that India is not poor and undeveloped country anymore as most of our people thought. So that, the reactualization of Indonesia - India relations becomes the possibly.

\section{THE NEEDS OF REACTUALIZATION OF INDONESIA-INDIA BILATERAL RELATIONS}

Before deeply discussing the need of reactualization of both countries relationship, it is quite important to realize that the future stage of the cooperation should be based on the historical matter of Indonesia-India relations. For that needs, here the dynamism of cooperation between both countries will be discussed.

\section{INDONESIAN-INDIAN RELATION BEFORE INDEPENDENT}

Indonesia and India relations have already begun 
more than 1000 years before it had been disrupted by colonial power. Indian had visited Indonesia since ancient time and Indonesia did maritime trade in most regions of South East Asian seas and India oceans. Since that time, mutual relationship had already appeared and influenced each other.

Cause of that relations, there are a lot of Indian influences to Indonesia such as cultures, languages and religions. Even the name of Indonesia which comes from latin and greek language has very close relations with India. Indonesia derives from word Hindus (India) and Nesos (island), which means that Indonesia is the islands of India.

Hindu, Budha and Islam in Indonesia also came from India through peaceful ways. Some traders from India did not only sell their goods, but also preached people to understand religions. Indonesia also was governed by some big and famous Hindu and Buddhist kingdom such as Sriwijaya and Majapahit (D.G.E.Hall: 1964). Therefore, Islam has very powerful influences to many aspects of people life in Indonesia.

Nowadays we still can see some evidences of those relations through some historical heritages such as many temples and hindu cultures in Indonesian society. For instance, in Bali sesajen ${ }^{3}$ still be the culture of people.

\section{INDONESIAN-INDIAN RELATIONS AFTER INDEPENDENT TO REFORMATION ERA}

In this era, Indonesia had two era, old order which means that Indonesian president was Soekarno who supported communism ideology from 1945 to 1965, and new order when Soeharto became Indonesian president since 1966 to 1998 and he liberalized Indonesian economy.

In the era of Soekarno, Indonesia and India relations was so close. India and Egypt were the the earlier countries which supported and recognized the Indonesian sovereignty. India was aginst Dutch in United Nations forum to recapture Indonesia and has officially opened diplomatic relations to Indonesia since 1951.
Moreover, in struggling against Dutch, Muhammad Ali Jinnah, the leader of All-Indian Muslim League sent more than 600 British Indian Army to help Indonesia. In 1955, Indonesia and Indian leaders, Soekarno and Jawaharlal Nehru, were among the five founders of the Non-Aligned Movement.

To understand more the history of Indonesia and India relations, I asked to former Indonesian Ambassador for India, Let.Gen.H.Andy Ghalib.SH,MH${ }^{4}$. He said that cause of those good relations, India gave very large area for Indonesian embassy in Delhi.

Unfortunately, the relations between both countries became not so good in the new order era in Indonesia. Soeharto who changed Soekarno position through "debatable" revolution ${ }^{5}$ totally rejected communism and socialism as ideology in Indonesia. Who joined this movement would be jailed even killed and their family till the end will never be accepted to be Indonesian civil servant. Soeharto was so strict to this rule since his background was military.

In contrast, he became so close to liberalism (America and her alliences). Then Soeharto built Indonesia through loans from IMF and World Bank. In term of growth, Indonesian economy raised significantly, but not in term of development. Gap between the rich and the poor in the same time increased drastically. Some of his friends and family also used Soeharto position for their own interests, and his regime become corruption, collusion and nepotism era. At the end, people felt disappointed with such kind of conditions and demanded Indonesian reformation. Finally, Soeharto resigned from his position as Indonesian president in 1998.

In this new order, the issue of Kashmir also influenced Indonesian people views to India. As majority moslems in the world, they felt sympathy on the condition of muslim people in Kashmir and regretted the policy of Indian government in using force and coercion.

This conditions absolutely influenced Indonesia and India relations. Before 1990s, India tended to be socialist country and Indonesia was liberalist country. Indonesia was close to America and India was close to 
Soviet Unions. The atmospher of cold war which was appeared in that time influenced the relations between both countries to be worse than in the old order era.

\section{INDONESIA-INDIAN RELATIONS IN POST REFORMATION}

In Indonesia post reformation, there were some Indonesian presidents, such as Habibi, Abdurrahman Wahid, Megawati Soekarno Putri and Susilo Bambang Yudhoyono. In three first presidents, the relation between Indonesia and India was not significantly being better because they tended to focus them selves to solve Indonesian domestic problems. Moreover, all of them became Indonesian president only in short time.

Habibie as a vice president in the era of Soeharto was influenced much by the issues of reformation to build clean government. People saw Habibie as the product and slave of Soeharto. Then, he resigned as a president only one year after governed Indonesia because people protested his policy on giving referendum to East Timor which has become independent state, separated from Indonesia.

Abdurrahman Wahid had complicated problems in his government era since he went to many countries around the world. On the other hand, people lived in suffer. He also had limitation on physical matter, so some of his policies were gotten by non-valid informations. Some of his policies were debatable, such as withdrawal the rules on limiting the freedom of socialist and communism people which had created in the era of Soeharto.

Then after became president for two years, he replaced by Megawati Soekarnoputri, his vice president. Again Megawati could not solve many domestic problems as there are a lot of "heritage problems" of previous presidents. She was protested by people because a lot of privatization policies she produced. For instance, she sold Indosat (one of biggest telephone channel in Indonesia) to Singapore.

Based on the explanation above, all of them almost could not repair Indonesia and Indian relations. Therefore, in this era, it was difficult to find and explain the achievements of Indonesia and Indian relations. Abdurrahman Wahid and Megawati in their period went to India, but the implementation or results of their visiting were not significant. That is why Susilo Bambang Yudhoyono becomes more important icon in rebuilding and re-emerging Indonesia and India relations.

\section{CURRENT INDONESIA-INDIA RELATIONS}

As president who has been governing Indonesia for two periods, SBY has more time to give his attention not only to domestic problems, but also to International relations. He also can conduct Indonesia to be more stable and better in term of economic development and politics. Therefore, he could visit India three times, in 2005 , one year after he became president in first period, 2011 and 2012 in his second period as Indonesian president.

In SBY era, India has being raising good achievement to be emerging powerful economic country in the world. India has very big potencies in term of populations, natural resources and civilization. Since 2004, Indian economic has been growing around 9 $\%$, leaves the previous condition in 1980s and 1990s which only gained 3,4\%.

Since Indonesia had good relation to India, it is time for both countries to repair their relations. Both countries as explained before have a lot of similarities, not only in previous time but also in this era. Till now, there are still a lot of cultures, religions and languages in Indonesia which are influenced by India. Boliwood films are still shown in Indonesian television and introduce a lot of Indian heritages and life realities to Indonesian people. In term of population, both countries face the same problems, such as poverty and gap between richs and poors people. They are also the democratic country in the world which can conducted some elections in peaceful manner though they have big number of populations.

Based on that conditions described above, Indonesia has some interests to India. Good relations between Indonesia and India will support economic development of both countries significantly. Moreover, as a developing country, Indonesia can learn 
more how to build Indonesian economic growth like what India has already done. Studying from Indian experiences will be much more compatible for Indonesia than study from developed countries since both countries have almost similar problems.

For instance, one of the most important ideas of Indian development which is very important for Indonesia is the concept of how to build the country from the village as Gandhi introduced. Moreover, Indian policy to give subsidy to education sector which makes the fees of educations in India is much more cheaper than in Indonesia is the other interesting point to be studied for Indonesian to make better public policy.

This Indonesian interest to cooperate closer to India is responded well by Indian government. Indian government also has some interests to Indonesia. As new emerging countries, India needs natural resources and more markets to sell their product. Indonesia is a very rich country in term of its natural resources. And as the forth largest population country in the world, Indonesia becomes potential market for India.

On the other hand, India government also has to give attentions to more than 100.000 Indonesian of Indian origins in which are living in Jakarta, Medan, Surabaya dan Bandung. Most of them are working in textiles and sports goods trade sector. In Indonesia, there are around 5.000 Indian nationals who are working as engineers, consultants, chartered accountants, bankers, and other professionals. Their living in Indonesia is very well and had enough prosperity. Even some of them become important people who hold strategic position in local and multinational corporations.

Navrekha Sharma in her writing stated that, Indonesia is important for India not only due to the economic considerations, but also the cultural relations. Except the long history of both countries relations, Indonesia is also willing to share their technology vice versa to India, something which cannot be done in relation to westerners and Japanese. (Navrekha Sharma:2011).

This relation is like brotherhood relations when each other try to help the difficulties of other nation. India helped Indonesia through operation Gambhir when Indonesia had tsunami disaster in 2005 (Vibhanshu Shekhar:2007). India sent a lot of number of foods and medical supplies for tsunami victims in Aceh, Indonesia, as Indian charity to its neighbor country. In that time, Indian gave assistance amount US\$ 1 million. In earthquake in Northern Sumatera on 28 March 2005, India also donated US\$ 2 million assistance. And there were others Indian assistance in earthquake in Java, Merapi volcanic and Mentawai.

Then India invited SBY, Indonesia president as the Chief Guest in her republic day, January 26, 2011. In that meeting, Indonesia and India signed Joint Statement Agreement for better relations after prime minister of India, H.E.Dr.Manmohan Singh, had intensive spoken to Indonesian president, H.E.Gen.Dr. Susilo Bambang Yudhoyono.

Some important points in that meeting are that both countries commit to recalled the establishment of diplomatic relations which has already begun since six decades ago. Then they have commitment to encourage the implementation of $\mathrm{MoU}$ in the field of agriculture through join research in agriculture science, technology development, on post harvest and processing, and market system. In term of education, both countries also will strengthen the cooperation on all level of education. Moreover, cooperation in some other important fields will be conducted such as the war against terrorism.

In term of economics, bilateral trade volumes between two countries had increased significantly, and they targeted that it can gain US4 25 billion by 2015 . To maximize that achievement, both leaders also agree to build Indonesia-India Comprehensive Economic Cooperation Agreement (II-CECA) as the media of economic negotiation between them. Both leaders also agreed to develop "vision statement 2025" which will be conducted through the guidance of Eminent Persons.

THE FUTURE OF INDONESIA AND INDIA RELATIONS 
India-Indonesia Trade Relations

\begin{tabular}{llllll}
\hline Year & $2005-2006$ & $2006-2007$ & $2007-2008$ & $2008-2009$ & $2009-2010$ \\
\hline Eksport & $1,380.20$ & $2,032.96$ & $2,164.17$ & $2,559.82$ & $3,063.36$ \\
Import & $3,008.11$ & $4,181.96$ & $4,821.25$ & $6,666.34$ & $8,656.66$ \\
Total Trade & $4,388.31$ & $6,214.92$ & $6,985.42$ & $9,226.17$ & $11,720.03$ \\
\hline \multicolumn{5}{c}{ Source: Ministry of Commerce of India, December, 2010 }
\end{tabular}

\section{THE POTENCIES}

Based on the explanation above, in recent time, Indonesia and India have better relations than in the new order era in Indonesia. This condition can be described in term of political and cultural relations and economic and trade relations.

\section{POLITICAL AND CULTURAL RELATIONS.}

Politically, Indonesia and India are democratic and secular countries. This condition makes relation between them becomes easier. For instance, both countries are committed to fight terrorism and radicalism. So, there is no power even by the name of religion or other group legally accepted to against people will. Indonesia and India also committed to multiculturalism, pluralism and diversity issues.

As countries which have big number of populations in the world, both countries also have same problems related to people which are still live in poverty. Gap between rich and poor people is so significant, so they can discuss and find the same format to solve that particular problem. That is why, in the meeting of SBY and Manmohan this year, they also discussed the commitment of both countries to upgrade their bilateral relation in achieving good progress and prosperity for the people in their countries.

Moreover, both countries also actively join the International forum such as ASEAN, ARF, East Asian Summit, G-20, United Nations, etc. This condition makes their relations which have a lot of similarities in term of cultures become closer. Both countries give scholarship to other country students to pursue their study in Indonesia or India, so the process of cultural exchanges and understanding can be implemented.

\section{ECONOMIC AND TRADE RELATION}

The first trade agreement between Indonesia and India was signed in January 1953. Then in 1978, both countries tried to strengthen and diversified trade. In 1986, both countries also signed the agreement to avoid double taxations in their trade (Vibhanshu Shekhar: 2007).

Their "ineffective" relations have already solved after Indonesian reformation when they had meeting in 1999, 2003 and 2004 to discuss the promotion and protection of investments. SBY which has become Indonesian president since 2004 then visited India in 2005 and signed MoU to create such kind of study group to examine the feasibility of comprehensive economic cooperation agreement.

The total value of bilateral trade has gone up from US $\$ 1.12$ billion in $1995-96$ to US $\$ 2.5$ billion in 2003-04 and reached US\$4 billion in 2005. The bilateral trade target has now been set at US $\$ 10$ billion by 2010. This conditions show that the relation between Indonesia and India become more and more significant and important for both countries. It is showed in this table above.

In tourism aspect, around 110,000 Indian tourists visited Indonesia in 2009 and the figure for Indonesian tourists visiting India for the same period was 6100. India has extended the Tourist Visa on Arrival Facility to Indonesian nationals, which is expected to boost tourist traffic between the two countries

\section{THE CHALLENGES}

Though Indonesia and India relations become better, but there are some conditions which have to be managed to avoid undesirable condition. If it is 
success to be done, then both countries can continuously build their relations to be better, be synergy in developing their powers and emerging as new powerful states.

In political aspects, Indonesia and India have to be care to the issue of Palestine and other Islamic countries issues. As the largest moslem country in the world, people in Indonesia often build public opinion which support Islamic world and influence Indonesian foreign policy.

In aspect of economic and trade, transportation is a big problems for Indonesia and India relations because until now, there is no Indonesia plane which flight to India, and vice versa. It can increase the price of production in both countries.

\section{CONCLUSION}

Based on the explanation above, it is clear that the relations of Indonesia and India have to be reactualized, to make it more intensive. At least we have two capital for this mission, the historical aspect and the emergence of India as new developed country. In term of history, the relations between Indonesia and India have already begun since thousand years ago. That relation does not only conducted before independent, but those relations continued after Indonesian independent. India is one of countries which support Indonesian independent from colonialism in united nation forums. Jawaharlal Nehru and Soekarno had very close relations. Both of them were famous as the founder of non-alignment movement.

Unfortunately those relations decreased significantly in the era of Soeharto (new order). Soeharto was closer to USA and India was closer to soviet unions. On the other hand, the issue of India-Pakistan also influenced Indonesia-India relations since people in Indonesia as the largest number of muslims in the world build public opinion to support muslim countries. As majority muslim country, most of Indonesia people supported the position of Pakistan.

But then, after Indonesian reformations 1998, especially in the era of SBY government, the relations between both countries are being much closer. For instance, the evidences show that the bilateral trade volume between both country has been increasing drastically. But, still both countries have to be care with some challenges which can break their relations. Therefore, the reactualization of the relations between those two country becomes important.

\section{ENDNOTES}

1 This is the revision of my paper which I have presented in International Conference on Good Governance and Sustainable Development, Annamalai University, India, 22nd \&23rd March 2012

3 The culture to bring some foods when they worship their God. These foods usually will be left in some particular places, ex; under the trees.

4 We often met in Indonesian embassy, Chanakya puri, and discussed the relations of Indonesia and India. One of meeting was conducted on 18 March, 2011. He really appriaciate to Indian government policies in developing India to be new emerging country in Asia.

5 There was G-30 S PKI (incident of Indonesian Communist Party movement on 30 September 1965 which wanted to change Indonesian ideology to be communist state by killing some military elites. Then cause of his incapability to keep state stability, Soekarno wrote mandate to Soeharto to get commando in stabilizing the condition which mean that Soeharto could become president. But the validity of this letter is still questioned.

\section{BIBLIOGRAPHY}

Bayuni, Endy. 2011. Indonesia-India Relations: It's Business as Unusual. Asia Pasific Bulletin, February 17, number 93.

D.G.E.Hall. 1964. A History of South East Asia. London: Macmillan\&CoLtd, Embassy of India. India-Indonesia Strategic Partnership. 2010. Warta India, May 15, Vol.III, Issue II.

Joint Statement. January 25, 2011. Vision for The India-Indonesia New Strategic Partnership Over The Coming Decade. (www.Indianembassyjakarta.com/Joint\%20Statement.pdf)

Sharma, Navrekha. January 20, 2011. Why Indonesia is Important to India?. Institute For Defence Studies\&Analyses. (http://www.idsa.in/issuebrief/Whylndonesiais/mportanttolndia). Shekhar, Vibhanshu, 2007. India-Indonesia Relations, an Overview. Institute of Peace and Conflict Studies Special Report. March. No.38. (http://www.idsa.in/IndialndonesiaRelations) 